\title{
Gap-filling alliance
}

\section{By Kai-Jye Lou, Staff Writer}

BioPontis Alliance LLC is taking a fresh approach to addressing the translational gap-instead of taking discoveries from universities and forming companies, BioPontis starts with its knowledge of industry's portfolio needs and works backward. The company hopes to close a $\$ 50$ million pilot fund by year end and start its first two R\&D projects early next year.

The model is one of a number of experiments that early stage investors are running to solve the translational gap. These include VCs such as Atlas Venture and Index Ventures that are setting up single-project companies with minimal infrastructure, ${ }^{1,2}$ as well as firms like PureTech Ventures that start with an unmet need, look for potential solutions in academia, then establish companies to drive these solutions to clinical and commercial milestones.

For BioPontis founder and CEO Richard Basile, the translational gap is characterized by a dearth of risk capital, a lack of scientific development expertise to develop technologies

"Our model avoids many of the costs associated with establishing a new company such as hiring management and building infrastructure."

-Richard Basile,

BioPontis Alliance LLC

\section{Relationships at both ends}

BioPontis was founded in 2009 as a combination of an investment fund and an R\&D company.

BioPontis' areas of focus are cancer, neurology, inflammation and infectious diseases. Thus far, the company has announced translational research agreements with three pharmas: Merck \& Co. Inc., Pfizer Inc. and most recently the Janssen Biotech Inc. unit of Johnson \& Johnson. BioPontis also has a network of eight university partners and plans to announce additional university partnerships this year.

BioPontis industry partners provide the firm with confidential guidance on priorities for their product portfolios, advice on product development objectives and experimental design, and access to technology development, market research and clinical resources.

Pharmas may even provide BioPontis with knowledge of negative data from the pharma's internal efforts against a target, noted Barbara Handelin, president and principal at BioPontis.

"These data give us details on what failed to work and why," she said. "Historically, details behind failures are rarely published and shared, but the industry is collectively realizing that it is losing a lot of value in repeating the same mistakes. These companies will also share in knowledge of the negative data from projects in the BioPontis portfolio that fail to meet criteria for advancement."

BioPontis uses its knowledge of industry's portfolio needs to guide the selection of technologies from its partners in academia, which BioPontis dubs University Alliance Partners.

The current University Alliance Partners are Columbia University, the Memorial Sloan-Kettering Cancer Center, New York University, the University of Florida, the University of Pennsylvania, the University of Virginia and The University of North Carolina at Chapel Hill. One University Alliance Partner has not yet been disclosed.

Under the deals with its University Alliance Partners, BioPontis gets nonexclusive access to the partners' IP portfolio. Technologies that make it past an initial triage stage are moved through a more formal due diligence step in which BioPontis receives a temporary, exclusive option on the technology.

BioPontis reviews the technology and determines whether or not it will license the IP. If BioPontis declines, the IP becomes available for licensing to other parties.

"Our model incentivizes us to identify failures, to focus resources on projects that appear to be more promising and to shift resources away from those that are starting to show signs of weakness," said Basile.

Red flags, he said, could come in the form of poor IP position or technical gaps.

For example, "A technology covering a biologic for cancer showed some very interesting effects and had a solid IP position, but we did not think we would be able to tease out a pragmatic synthesis approach that would meet regulatory and manufacturing requirements," Basile told SciBX. "The technical gaps made this particular technology unsuitable for further consideration.' 
If a technology passes the diligence phase, BioPontis takes an exclusive worldwide license to the technology for all uses. The university receives no up-front payment, receiving instead a prorated share of the total value generated in any deal BioPontis does for the technology.

According to Basile, this deal structure incentivizes both BioPontis and its university partner to work together to maximize the exit value of technology assets.

Once BioPontis licenses a technology, its job is to establish a development plan, carry out validation studies and enhance the existing IP position by moving suitable candidates and leads through INDenabling studies.

"We have lead development scientists to take care of our technology assets," said Basile. "They are responsible for overseeing the development pathway and the experiments that are to be carried out. Our board will review the development and progress of each asset and take a Darwinian view on which assets to continue developing."

The development scientists use the resources in BioPontis' R\&D network, which include CROs like Taconic Farms Inc., to carry out validation studies.

"We anticipate exiting assets from BioPontis that have at minimum reached an optimized small molecule, protein or antibody that would be ready for clinical testing," said Basile. "The most mature exit would be after a first-in-human study, which could be a Phase 0 trial or a proof-of-biology study."

Basile expects the majority of exits for BioPontis' technology assets will be licensing deals in which an industry partner receives rights to the asset in exchange for an up-front payment, milestones and royalties. He said another potential exit scenario could involve the industry partner paying BioPontis to continue incubating the asset.

\section{Company milestones}

BioPontis hopes to close its $\$ 50$ million pilot fund by year end. The company's goal is to mine through 1,000-2,000 technology assets by year 3 of the fund, vet and invest in 15-25 assets by year 5 and exit 5 assets at the optimized lead or the IND-ready stage in years 4-10.

BioPontis hopes to raise a second, larger fund as it is able to establish the scalability and reproducibility of its model.

The firm is conducting diligence on 6 assets and plans to move 2 of these technologies into development within 90 days of closing the pilot fund.

One of the assets in the final stages of diligence covers the target hormonally up-regulated Neu-associated kinase (HUNK; B19). In February, researchers at the Perelman School of Medicine at the University of Pennsylvania published a study suggesting that a HUNK inhibitor might increase breast cancer susceptibility to existing antiHER2 (EGFR2; ERBB2; neu) therapeutics. ${ }^{3,4}$

Lou, K.-J. SciBX 4(30); doi:10.1038/scibx.2011.844

Published online Aug. 4, 2011

REFERENCES

1. Flores, D. \& Bernstein, K. BioCentury 17(40), A1-A10; Sept. 14, 2009

2. Lawrence, S. BioCentury 19(10), A13-A14; Feb. 28, 2011

3. Yeh, E.S. et al. J. Clin. Invest. 121, 866-879 (2011)

4. Martz, L. SciBX 4(10); doi:10.1038/scibx.2011.271

COMPANIES AND INSTITUTIONS MENTIONED

Atlas Venture, Cambridge, Mass.

BioPontis Alliance LLC, Raleigh, N.C.

Columbia University, New York, N.Y.

Index Ventures, London, U.K.

Johnson \& Johnson (NYSE:JNJ), New Brunswick, N.J.

Memorial Sloan-Kettering Cancer Center, New York, N.Y.

Merck \& Co. Inc. (NYSE:MRK), Whitehouse Station, N.J.

New York University, New York, N.Y.

Perelman School of Medicine at the University of Pennsylvania, Philadelphia, $\mathrm{Pa}$.

Pfizer Inc. (NYSE:PFE), New York, N.Y.

PureTech Ventures, Boston, Mass.

Taconic Farms Inc., Hudson, N.Y.

University of Florida, Gainesville, Fla.

The University of North Carolina at Chapel Hill, Chapel Hill, N.C.

University of Pennsylvania, Philadelphia, Pa.

University of Virginia, Charlottesville, Va. 